\author{
ALEKSANDRA JÓZEFCZYK, JOANNA KOWALSKA \\ Katedra i Zakład Farmakognozji z Pracownia Roślin Leczniczych \\ Uniwersytet Medyczny $w$ Lublinie \\ Chodźki 1, 20-093 Lublin \\ E-mail: ajozefczyk@pharmacognosy.org
}

\title{
OCENA SKEADU I ZASTOSOWANIE OLEJKÓW ETERYCZNYCH Z RODZAJU CENTAUREA L.
}

\section{WSTEP}

Olejki eteryczne pozyskiwane i wykorzystywane sa przez człowieka od wieków. Ich wieloskładnikowa kompozycja, nieraz bogata w unikatowe substancje, przejawiajace cenne właściwości, stanowi przedmiot licznych badań. Nie jest do końca poznana rola olejków eterycznych w funkcjonowaniu roślin, jednak wiadomo, że biora one udział w wielu istotnych procesach i $z$ tej przyczyny sa niekiedy nazywane hormonami roślinnymi. Liczne źródła, a także fakt, że olejki znajduja się we wszystkich roślinach, potwierdzaja tę teorię. Olejki eteryczne sa wykorzystywane w różnych dziedzinach życia, takich jak medycyna, aromaterapia, ale również $\mathrm{w}$ przemyśle farmaceutycznym, kosmetycznym, chemicznym czy spożywczym. W ostatnich latach uwaga badaczy skupiła się na olejkach eterycznych pozyskiwanych $z$ gatunków Centaurea L, które wykorzystywane sa jako rośliny lecznicze w medycynie ludowej wielu krajów. Rodzaj Centaurea L. jest jednym z liczniejszych rodzajów rodziny Asteraceae, jednak jego morfologia i chemizm wciąż jeszcze nie sa dobrze poznane. Centaurea L. jest polimorficznym, czwartym co do wielkości rodzajem należącym do rodziny Asteraceae, zaliczającym się do grupy roślin okrytonasiennych (kwiatowych). Obejmuje on najczęściej wieloletnie, ale również roczne i dwuletnie gatunki roślin trawiastych i krzewinek. "The Plant List" podaje 2753 nazwy naukowe gatunków rodzaju Centaurea L., z czego 734 nazwy sa gatunkami akceptowanymi. Gatunki Centaurea L. badano pod względem morfologicznym, molekularnym i filogenetycznym. Wielkość genomu tego gatunku waha się od $2 \mathrm{C}=1,67$ do 4,30 pg. Dane kariologiczne dla tych taksonów sa skape i skupiaja się przede wszystkim na określeniu liczby chromosomów, natomiast badania kariotypu zostały wykonane tylko dla kilku gatunków. Rodzaj Centaurea L. ma kilka podstawowych liczb chromosomów, począwszy od $\mathrm{x}=7$ do $\mathrm{x}=16$. Biorac pod uwage te podstawowe wartości, rodzaj ten wydaje się składać w większości $z$ gatunków diploidalnych i tetraploidalnych (DYDAK i współaut. 2009).

Pod względem budowy takson ten jest bardzo zróżnicowany i wymaga dalszych badań, wykorzystujacych głównie nowoczesne techniki cytologiczne i chemiczne. Ujednolicenie opisu tego rodzaju jest bardzo dużym problemem, wynikającym ze znacznych różnic morfologicznych, kariologicznych i palinologicznych roślin (DURAL I WSPÓŁAUT. 2003). Analiza budowy morfologicznej i składu chemicznego roślin $z$ rodzaju Centaurea L., w powiazaniu $z$ pozyskiwanymi $z$ nich olejkami eterycznymi, dają możliwość wykorzystania tych substancji roślinnych w farmakologii i medycynie powszechnej. W niniejszej pracy przedstawiono przeglacd olejków eterycznych pozyskiwanych $z$ wybranych gatunków roślin rodzaju Centaurea L., ze szczególnym uwzględnieniem ich składu oraz związków w nich dominujących. Opisano właściwości tych olejków, na podstawie których można przewidywać ich potencjalne wykorzystanie w wielu gałęziach przemysłu. 


\section{WYSTEPOWANIE}

Rośliny $z$ rodzaju Centaurea L. występuja głównie w obszarze Morza Śródziemnego i Zachodniej Azji. Rodzaj ten jest jednym z najbogatszych pod względem występowania gatunków endemicznych. Szczególnie duża liczbę gatunków Centaurea L. spotkać możemy w Turcji, gdzie, zaraz po Astragalus i Verbascum, jest trzecim pod względem liczebności rodzajem, reprezentowanym przez ok. 182 gatunki, w tym 113 endemiczne. Sa one rozpowszechnione głównie $\mathrm{w}$ południowo-zachodniej, centralnej i wschodniej części kraju. Współczynnik endemiczny jest dość wysoki i wynosi $62,1 \%$ (KAHRIMAN i współaut. 2012). W Iranie rodzaj ten reprezentuja 74 roczne lub wieloletnie gatunki zielne, które rozmieszczone sa na terenie całego kraju, z czego 38 to gatunki endemiczne (ESMAEILI i współaut. 2005).

\section{SKŁAD OLEJKÓW POZYSKIWANYCH Z ROSLIN $Z$ RODZAJU CENTAUREA L.}

Opisano poniżej 50 przykładowych substancji pochodzenia roślinnego. Olejki eteryczne, otrzymywane były głównie na drodze destylacji $z$ para wodna.

Centaurea aladagensis Wagenitz jest wieloletnim gatunkiem endemicznym, spotykanym na obszarze Turcji. Roślina ta dorasta do $40 \mathrm{~cm}$ wysokości, ma słabo owłosione liście i kwiaty barwy fioletowej. W olejku eterycznym pochodzacym $z$ części nadziemnych tego gatunku, zidentyfikowano 85 zwiazków, których łączna zawartość wynosiła 87,3\%. Skład olejku okazał się bogaty w kwasy thuszczowe, estry i seskwiterpeny tlenowe i wykazywał działanie przeciwbakteryjne w stosunku do Staphylococcus epidermidis. Do głównych składników olejku eterycznego należały: kwas palmitynowy $(39,3 \%)$, tlenek kariofilenu $(6,6 \%)$ i heksahydrofarnezylo-aceton $(4,3 \%)$ (FLAMINI i współaut. 2006, BŸLENT KOSE i współaut. 2007).

Centaurea antiochia Bioss. jest wieloletnia roślina dorastajaca do $100 \mathrm{~cm}$ wysokości, z liśćmi owłosionymi lub nieznacznie owłosionymi, oraz czarno-fioletowymi kwiatami. Należy do gatunków endemicznych, pochodzących $z$ terenów Turcji. Spośród wielu zwiazków występujących w olejku eterycznym tego gatunku, otrzymanym $z$ kwiatów, dominującym składnikiem okazał się germakren D $(45,1 \%)$, a w mniejszych ilościach wystepowały: $\beta$-kariofilen (4,5\%), spatulenol $(3,3 \%)$ oraz dekanal $(0,6 \%)$ (FLAminI i współaut. 2006).

Cenaturea antitauri Hayek to gatunek endemiczny dla Turcji. Jest wieloletnia roślina charakteryzujaca się $45 \mathrm{~cm}$ prosta ło- dyga, liśćmi $z$ przegrodami oraz kwiatami o żółtej barwie. Do składników wyizolowanego z kwiatów olejku eterycznego należały germakren D $(40,2 \%)$ i $\beta$-kariofilen $(13,5 \%)$. (FLAMINI i współaut. 2006).

Do ekstrakcji olejku eterycznego $\mathrm{z}$ Centaurea appendicigera K. Koch (syn. Psephellus appendicigerus (K. Koch) Wagenitz) wykorzystano całą wysuszona roślinę. Olejek zawierał łącznie 45 zwiazków, stanowiących $85,5 \%$ całego destylatu, a jego głównymi składnikami były: tlenek kariofilenu $(17,1 \%)$, $\beta$-kariofilen (17,5\%), n-heptakozan $(1,6 \%)$, cis-fitol $\quad(0,5 \%), \quad(\mathrm{E})-\beta$-damascenon $\quad(1,8 \%)$ (YAYLI i współaut. 2009).

Centaurea armena Boiss. jest wieloletnim gatunkiem endemicznym dla Turcji, występującym głównie na terenach wschodniej Anatolii. Olejek eteryczny, pozyskany $z$ całych roślin, zawierał $w$ swoim składzie 20 zwiąków, które stanowiły łącznie 82,7\% zidentyfikowanych zwiazków. W największych ilościach występowały $\beta$-eudesmol $(19,3 \%)$, kalaren $(10,3 \%), \quad 6,10,14$-trimethyl-2-pentadekanon $(5,7 \%)$ oraz $\beta$-kariofilen $(5,4 \%)$ (YAYLI i współaut. 2005).

Centaurea aucheri (DC.) Wagenitz jest roślina wieloletnia występująca na terenie całego Iranu. Nadziemne części dzikorosnacych roślin zostały zebrane w okresie kwitnienia i wysuszone $\mathrm{w}$ warunkach naturalnych. Pozyskany $z$ nich olejek eteryczny o silnym aromacie, zawierał 22 zwiazki, które stanowiły łącznie $80,03 \%$ olejku, bogatego w węglowodory seskwiterpenowe $(50,1 \%)$ oraz seskwiterpeny zawierające tlen $(27,24 \%)$. Głównymi składnikami były tlenek kariofilenu $(19,44 \%), \beta$-kariofilen $(14 \%)$ oraz germakren D (13,38\%) (ASADIPOUR i współaut. 2005).

Centaurea babylonica (L.) L. jest dwuletnia roślina dorastajaca do $300 \mathrm{~cm}$ wysokości, $z$ szaro-owłosionymi liśćmi i żółtymi kwiatami. Głównymi składnikami olejku eterycznego, pozyskanego $z$ ziela były: germakren D (43\%) oraz $\beta$-kariofilen (9,9\%) (FLAMINI i współaut. 2006).

Centaurea balsamita Lam. [syn. Stizolophus balsamita (Lam.) K. Koch] to jednoroczna roślina, dorastajaca do $120 \mathrm{~cm}$ wysokości. Gatunek ten wyróżnia się chropowatymi liśćmi, a jego kwiaty mają barwę żółta. Do głównych zidentyfikowanych zwiazków zawartych w olejku eterycznym, pozyskanym $z$ kwiatów należą: germakren D $(40,2 \%)$, spatulenol $(2,2 \%)$ oraz $\beta$-kariofilen $(1,7 \%)$ (FLAMINI i współaut. 2006).

Centaurea cadmea Boiss. jest gatunkiem endemicznym dla Turcji, należącym do sekcji Acrolophus-Phalolepis. Olejek eteryczny został pozyskany $\mathrm{w}$ procesie mikrodestylacji wysuszonych, nadziemnych części roślin. Analizie poddano dwa olejki, pozyskane $z$ 
roślin tego samego gatunku (C1 i C2), zebranych w oddalonych od siebie miejscach. Związki wchodzące w skład olejków stanowiły 88,1\% olejku C1 i 86,3\% C2. Zwiazkami dominujacymi w $\mathrm{C} 1$ były: kwas palmitynowy $(23,1 \%)$, karwakrol $(14,7 \%)$, kwas dodekanowy $(4,4 \%)$, fitol $(4,1 \%)$, kwas tetradekanowy $(4,1 \%)$, heptakozan $(3,8 \%)$, a w C2: kwas palmitynowy $(19,5 \%)$, karwakrol $(16,6 \%)$, fitol $(6,0 \%)$, kwas dodekanowy $(5,3 \%)$, kwas tetradekanowy (4,1\%), heptakozan (4,1\%). Porównanie próbek C. cadmea Boiss., zebranych $z$ dwóch różnych lokalizacji, wykazało podobieństwo jakościowe i ilościowe w odniesieniu do obecności głównych składników. Niewielkie różnice obserwowane w analizie tych dwóch olejków moga być związane z różnymi czynnikami glebowymi (KARAMENDERES i współaut. 2008).

Centaurea calcitrapa L. jest dwuletnia rośliną trawiasta, rosnaca dziko na tenarach Europy południowej, w szczególności na Sycylii. Gatunek ten preferuje żyzne mady i tworzy geste kepy na pastwiskach, leśnych łakach i na terenach nadrzecznych. Osiaga do $60 \mathrm{~cm}$ wysokości, kwitnie od lipca do sierpnia, a jego kwiaty sa hermafrodytyczne. Roślina ta lokalnie nazywana jest "fiordaliso stellato”, czyli „chaber gwiaździsty”. Jego liście wykorzystywane sa w gastronomii, głównie do przyrządzania sałatek. W Ameryce Północnej i Południowej, Australii i Nowej Zelandii C. calcitrapa L. uważany jest za chwast inwazyjny, ze względu na wysteppowanie w szerokim zakresie warunków środowiskowych, zdolny do pogorszenia jakości parków i terenów naturalnych, przez zastąpienie gatunków rodzimych. Bladożółtej barwy olejek eteryczny, pozyskany ze świeżych kwiatów C. calcitrapa L. nie wykazywał specyficznego zapachu. Zwiąkami dominujacymi w składzie olejku okazały się węglowodory $(32,3 \%)$ i kwasy tłuszczowe $(32,8 \%)$. Do głównych związków należały: kwas 9,12-oktadekadienowy $(15,8 \%)$ oraz trikozan (8\%). Obecne były również seskwiterpeny, w postaci węglowodorów $(10,1 \%$ dla 14 składników) oraz tlenowych pochodnych $(2,0 \%$ dla 4 składników), spośród których związkami najliczniejszymi były: $\beta$-bisabolen $(2,0 \%)$, germakren D $(1,8 \%)$ i kariofilen $(1,6 \%)$ (SENATORE i współaut. 2006, DiTOMASO i współaut. 2013).

Centaurea calolepis Boiss., zaliczany do sekcji Acrolophus, jest roślina endemiczna wysteppujaca w Turcji na terenie zachodniej i południowej Anatolii. Olejek eteryczny został wyizolowany $z$ wysuszonych, nadziemnych części roślin, które zostały poddane procesowi mikrodestylacji. Analiza olejku pozwoliła na zidentyfikowanie 82 zwiazków, które łącznie stanowiły 88,6\% składu olejku.
Do głównych związków należały: kwas palmitynowy $(27,3 \%)$, karwakrol $(18,9 \%)$, fitol $(3,4 \%)$, kwas tetradekanowy $(3,2 \%)$, spatulenol (3,1\%) (KARAMENDERES i współaut. 2008).

Centaurea cariensis Boiss. subsp. maculiceps (O. Schwarz) Wagenitz (CCMA) oraz Centaurea cariensis Boiss. subsp. microlepis (Boiss.) Wagenitz (CCMI) zaliczane sa do sekcji Acrolophus-Phalolepis. Sa to rośliny endemiczne, występująca na obszarze Turcji. Olejki eteryczne uzyskane poprzez mikrodestylację wysuszonych, nadziemnych części roślin, jako główne składniki zawierały w CCMA: karwakrol (13,0\%), 4-methyl-4-hepten-3-one $(12,8 \%)$, kwas palmitynowy $(4,9 \%)$, kwas dodekanowy (4,1\%) i (Z)-3-heksenal (4,0\%), a w CCMI: karwakrol (28,4\%), kwas palmitynowy $(10,0 \%)$, kwas dodekanowy $(4,6 \%)$ i fitol $(4,3 \%)$ (KARAMENDERES i współaut. 2008)

Centaurea cheirolepidoides Wagenitz jest to także wieloletni gatunek endemiczny dla Turcji. Roślina dorasta do $40 \mathrm{~cm}$ wysokości, posiada szarawo-owłosione liście i kwiaty o żółtej barwie. Spośród wielu zidentyfikowanych zwiazków wchodzacych w skład olejku eterycznego, pozyskanego $z$ całych kwiatów, w najwyższym stężeniu występowały: germakren D $(21,7 \%)$, $\beta$-kariofilen $(14,4 \%)$ oraz tlenek kariofilenu $(6,1 \%)$ (FLAMINI i współaut. 2006).

Centaurea chrysantha Wagenitz jest roślina wieloletnia, posiadajacca wzniesiona łodygę zakończona kwiatostanem osiagajaca wysokość 5-10 cm; roślinę charakteryzuja żółte kwiaty i lancetowate liście, $z$ gęstymi, białym włoskami po obu stronach. C. chrysantha Wagenitz jest rzadkim gatunkiem endemicznym sekcji Acrocentron, charakterystycznym dla pasma górskiego Aladaglar w Turcji. Rośnie na skalistych i kamienistych zboczach $z$ brunatnymi glebami leśnymi i preferuje półpustynny, chłodny klimat śródziemnomorski $z$ roczna suma opadów ok $400 \mathrm{~mm}$. Olejek eteryczny otrzymany ze świeżych kwiatostanów zawierał 76 związków, które łącznie stanowiły $87,1 \%$ jego składu. Monoterpeny, podobnie jak weglowodory i pochodne tlenowe, były w olejku prawie nieobecne. Wśród weglowodorów znaleziono jedynie śladowe ilości a-pinenu, a-felandrenu oraz limonenu. Najliczniejsza grupa zwiazków okazały się seskwiterpeny, a germakren D był głównym składnikiem stanowiącym $27,4 \%$ olejku. Olejek zawierał również $5,4 \%$ bicyklogermakrenu, 4,2\% $\beta$-kariofilenu oraz 9,5\% tlenku kariofilenu. Ponadto zidentyfikowano: a-kadinol $(2,6 \%)$, globulol $(1,8 \%), \beta$-bisabolen $(1,2 \%)$, trans-nerolidol $(0,7 \%)$, gwajol $(0,6 \%)$ oraz $(\mathrm{E})$ $\beta$-farnezen $(0,4 \%)$. Olejek eteryczny zawierał również wiele nieterpenowych aldehydów alifatycznych o łańcuchach prostych, razem $z$ 
aromatycznymi pochodnymi benzaldehydu i fenyloacetaldehydu, które łacznie stanowiły 12,8\% (DURAL i współaut. 2003).

Centaurea cineraria L. subsp. umbrosa (Lacaita) Pign to gatunek endemiczny dla zachodniej części Sycylii. Jest to wieloletnia roślina rosnaca wzdłuż klifów. Jej cechą charakterystyczna są duże koszyczki kwiatowe $z$ czerwono-fioletowymi kwiatami. Olejek eteryczny, o bladożółtej barwie i kleistej konsystencji, pozyskany został ze świeżych kwiatów. Łącznie zidentyfikowano 55 zwiąków stanowiących $89,7 \%$ olejku, w składzie którego największy udział miały seskwiterpeny $(44,9 \%)$. Do głównych substancji należały: germakren D $(22 \%)$, kariofilen $(8,6 \%)$, tlenek kariofilenu (3,2\%) oraz kwas palmitynowy (20,8\%) (SENATORE i współaut. 2003).

Centaurea cuneifolia Sibth. \& Sm. należy do sekcji Acrolophus. Ta dwuletnia roślina charakteryzuje się zazwyczaj wznoszaca się i bardzo rozgałęziona łodyga o wysokości 30-60 cm oraz pierzastosiecznymi, prawie bezwłosymi liśćmi $z$ waskimi segmentami. Koszyczki kwiatowe sa stosunkowo małe, a przylistki, jeśli występuja, sa krótko zbiegające się u podstawy, zazwyczaj strzępiaste. C. cuneifolia Sibth. \& Sm. występuje na terenie południowo-wschodniej części Półwyspu Bałkańskiego. $Z$ części nadziemnych roślin otrzymano jasno-żółty olejek eteryczny, w którym zidentyfikowano 78 związków, stanowiacych 92,6\% wszystkich zwiazków. Analiza składu wykazała, że jest on bogaty w terpenoidy $(55,2 \%)$. Główną grupa związków okazały się seskwiterpeny tlenowe, a wśród nich dominowały: $\beta$-eudesmol (26,5\%), spatulenol $(6,3 \%)$ i tlenek kariofilenu $(2,9 \%)$. W skład olejku wchodziło również 6 kwasów tłuszczowych, stanowiących łącznie 23,1\%, z których w najwyższym stężeniu były: kwas palmitynowy $(17,6 \%)$ i kwas $(Z, Z)-9,12$-oktadekanowy $(2,4 \%)$. Weglowodory nie występowały w dużej ilości $(6,2 \%)$, a związki zawierajace grupę karbonylowa reprezentowane były przez 14 substancji (5,7\%). Zidentyfikowano także 13 innych zwiąków, bardzo rzadkich w olejkach eterycznych, pozyskiwanych $z$ roślin rodzaju Centaurea L. (RosselLI i współaut. 2009).w olejkach eterycznych pozyskiwanych $z$ roślin rodzaju Centaurea L. (Rosselli i współaut. 2009).

Centaurea cyanus L. (syn. Cyanus segetum Hill), znany w Polsce jako chaber bławatek, jest gatunkiem $z$ rodziny Astrowatych, należącym do sekcji Cyanus. Występuje powszechnie na terenie całej Europy i Syberii Zachodniej. Roślina ta uważana jest za pospolity chwast; dzięki niewielkim wymaganiom siedliskowym rośnie na wszystkich glebach, w szczególności możemy go spotkać na polach $z$ uprawami rzepaku, zbóż ozimych oraz roślin okopowych i motylkowych. Chaber bławatek jest gatunkiem jednorocznym, miododajnym, osiagajacym od 30 do $90 \mathrm{~cm}$ wysokości. Koszyczki kwiatowe charakteryzuja się niebieską barwą kwiatów rurkowatych. Jako roślina lecznicza wykazuje działanie moczopędne, jest także stosowany w stanach zapalnych oczu; 5\% napar $z$ suszonych kwiatów chabra bławatka, wykorzystywany jest w leczeniu biegunki, na zwiększenie apetytu, a także do łagodzenia ucisku w klatce piersiowej. W olejku eterycznym wyizolowanym $z$ części nadziemnych, zidentyfikowano 88 zwiazków, stanowiacych łącznie 85,4\% składu olejku. Najliczniejszymi grupami okazały się monoterpeny tlenowe $(29,9 \%)$ i kwasy tłuszczowe $(16 \%)$. Dominującymi składnikami olejku eterycznego były: karwakrol (25,5\%), kwas palmitynowy $(6,4 \%)$ i tlenek kariofilenu $(2,8 \%)$ (KoHLMÜNZER 1998, KARAMENDERES i współaut. 2008, KOCA i współaut. 2009).

Centaurea deflexa Wagenitz jest wieloletnia roślina $z \quad 5-30 \mathrm{~cm}$ płożąca się łodyga. Liście sa gęsto owłosione, a kwiaty maja barwę żółta. Jest to gatunek endemiczny dla Turcji. Zwiazkiem dominujacym w składzie olejku pozyskanego $z$ kwiatów okazał się $\beta$-kariofilen, którego stężenie wynosiło 33,9\%. W znacznej ilości występowały również: germakren D $(21,2 \%)$ i tlenek kariofilenu $(12,8 \%)$ (FLAMINI i współaut. 2006).

Centaurea depressa M. Bieb. [syn. Cyanus depressus (M. Bieb.) Soják] jest to roślina najczęściej spotykana na terenach południowo-zachodniej i środkowej Azji. Olejek eteryczny, uzyskany $z$ wysuszonych części nadziemnych, jako główne składniki zawierał: kwas palmitynowy $(21,3 \%)$, karwakrol $(14,2 \%)$, kwas tetradekanowy $(8,8 \%)$, kwas dodekanowy (4,7\%) (KARAMENDERES i współaut. 2008).

Centaurea dichroa Boiss. \& Heldr. jest endemiczna roślina pochodzaca $z$ Turcji. Materiałem roślinnym, wykorzystanym do pozyskania olejku eterycznego, były wysuszone w warunkach naturalnych nadziemne części roślin. Otrzymany olejek eteryczny zawierał 85 związków, które stanowiły łącznie $76,4 \%$ zawartości, a głównymi jego składnikami były: kwas palmitynowy $(11,8 \%)$, tlenek kariofilenu $(9,8 \%)$ i spatulenol $(5,8 \%)$ (Altintas i współaut. 2004).

Centaurea ensiformis P.H. Davis jest tureckim gatunkiem endemicznym, który wystepuje na glebach serpentynitowych. Jego cechy morfologiczne nie pozwalaja na wyraźne przypisanie do żadnej $z$ istniejacych sekcji, jednak został on umieszczony w grupie Cheirolepis-Pseudoseridia. Olejek eteryczny pozyskany $z$ wysuszonych nadziemnych części roślin, jako główne związki zawierał: kar- 
wakrol (17.4\%), kwas palmitynowy $(13,2 \%)$, fitol $(6,0 \%)$, heptakozan $(3,0 \%)$ i tlenek kariofilenu (2,3\%) (KARAMENDERES i współaut. 2008).

Centaurea eryngioides Lam. jest roślina dziko rosnąca w Libanie, występująca na terenie lasów cedrowych Tanourine. Wodny ekstrakt z C. eryngioides Lam. wykazuje silna aktywność hamująca wobec Plasmodium falciparum. Olejek eteryczny pozyskanego $Z$ części nadziemnych ma jasno-żółtą barwę i nie wykazuje charakterystycznego zapachu. Analiza składu wykazała obecność 70 zwiąków, które stanowiły 95,8\% jego zawartości. Wśród wielu różnorodnych substancji, grupami dominujacymi w składzie olejku, okazały się kwasy tłuszczowe $(43,5 \%)$ i weglowodory (12,2\%). Seskwiterpeny znajdowały się w stosunkowo dużym stężeniu (węglowodory - 6,5\%, seskwiterpeny zawierajace tlen - 19,8\%). Zwiazkami głównymi olejku eterycznego były: kwas palmitynowy $(33,2 \%)$, $\beta$-eudesmol $(6,2 \%)$ i tlenek kariofilenu $(4,3 \%)$ (SENATORE i współaut. 2005).

Centaurea euxina Velen. należy do sekcji Phalolepis i jest gatunkiem endemicznym w Bułgarii, występujacym na piaskach morskich w północno-wschodniej części kraju. Jest to roślina dwuletnia, o łodydze długości 10-20 cm, mocno rozgałęzionej od podstawy. Liście sa szaro-zielone, lekko owłosione, kwiaty różowe. Destylacja $z$ para wodną nadziemnych części rośliny pozwoliła na uzyskanie bladożółtego olejku eterycznego. Wśród 69 zidentyfikowanych związków, stanowiacych 92,1\% jego składu, najliczniejszymi okazały się: terpenoidy $(41,1 \%)$ i seskwiterpeny tlenowe (14 związkow stanowiących 27,1\%). Głównymi składnikami olejku były: spatulenol (10,8\%), tlenek kariofilenu (6,2\%) i $\beta$-eudesmol (3,9\%). Zidentyfikowano także dużą grupę związków diterpenowych (9,8\%), wśród których głównym składnikiem był fitol $(6,7 \%)$. Z olejku wyodrębniono także $6 \mathrm{kwa}-$ sów tłuszczowych, których stężenie łącznie wyniosło 24,5\%, a dominującym zwiazkiem tej grupy był kwas palmitynowy (20,3\%) (RosSELLI i współaut. 2009).

Centaurea hadimensis Wagenitz, K. Ertugrul \& H. Dural (syn. Psephellus hadimensis Wagenitz) jest bardzo rzadka roślina endemiczna występujaca w Południowej Anatoli. Gatunek ten należy do sekcji Psephelloideae. Wykazuje on podobieństwo do Centaurea pseudoscabiosa Boiss. \& Bushe i rośnie w zbliżonych warunkach. Olejek eteryczny pozyskiwany był na drodze destylacji $z$ para wodna świeżych kwiatów. Zidentyfikowano w nim 70 zwiazków, które stanowiły 94,2\% składu olejku. Pomimo obecności w nieco większych ilościach a-pinenu, $\beta$-pinenu, a-felandrenu, $p$-cymenu i ocymenu, mono- terpeny występowały w niewielkich ilościach. W tym przypadku głównymi składnikami olejku okazały się seskwiterpeny, $z$ przewaga germakrenu D $(44,3 \%)$, a także $\beta$-kariofilen $(9,8 \%)$, bicyklogermakren $(7,9 \%)$, spatulenol $(3,5 \%)$ i tlenek kariofilenu $(3,1 \%)$ (FLAMINI i współaut. 2002). Olejek eteryczny pozyskany $z$ części nadziemnych Centaurea helenioides Boiss \& Hausskn. ex Boiss. zawieral 51 związków stanowiących łącznie 83,7\% składu, $z$ których dominującymi okazały się: tlenek kariofilenu $(18,2 \%)$, germakren D $(7,3 \%)$, dihydroedulan I $(2,6 \%)$, cis-fitol $(6,2 \%)$ i pentadekanal $(1,7 \%)$ (YAYLI i współaut. 2009).

Centaurea hierapolitana Boiss. zaliczana jest do sekcji Acrolophus-Phalolepis. Jest to roślina endemiczna dla Turcji. Olejek eteryczny został pozyskany w procesie mikrodestylacji wysuszonych, nadziemnych części roślin. Dominujacymi związkami olejku były: kwas palmitynowy (33,4\%), karwakrol $(13,3 \%)$ i kwas tetradekanowy $(4,4 \%)$ (KARAMENDERES i współaut. 2008).

Olejek eteryczny $z$ gatunku Centaurea huber-morathii Wagenitz (syn. Psephellus huber-morathii (Wagenitz) Wagenitz) pozyskiwany był $z$ pokruszonych nasion $w$ procesie mikrodestylacji. Analiza produktu ujawniła 85 związków stanowiących łącznie 83,2\% składu olejku eterycznego. Głównymi składnikami były: oktanol $(17,8 \%)$ i kwas palmitynowy (8\%). W dość dużym stężeniu występowały również $p$-cymen (4,9\%) i tlenek kariofilenu $(3,3 \%)$. Węglowodory oraz ich tlenowe pochodne (alkohole, aldehydy, ketony) były obecne w większej ilości, osiagajacc 35\% zawartości olejku. Wśród alkanów, zawartością wyróżnił się pentakozan $(1,2 \%)$ i trikozan (1\%). Spośród tlenowych pochodnych dominowały alkohole $(18,6 \%)$ i aldehydy $(10,5 \%)$, natomiast ketonów było znacznie mniej (0,6\%). Oktanol, alkohol alifatyczny, nigdy wcześniej nie był opisany jako główny składnik olejków w innych gatunkach rodzaju Centaurea L. Badania porównawcze z głównymi zwiazkami lotnymi wśród gatunków Centaurea L. wskazuja, że olejek C. huber-morathii Wagenitz ma unikatowy skład ze względu na wysoka zawartość węglowodorów (BASER i współaut. 2006).

Centaurea iberica Trev. ex Spreng. var. hermonis Boiss. Lam. jest gatunkiem jednorocznym, pochodzacym $z$ obszaru południowo-wschodniej Eurazji. Roślina ta preferuje tereny wilgotne. Dorasta do około 90 $\mathrm{cm}$ wysokości, łodygi ma wyprostowane, $z$ silnie rozgałęzionymi pędami i licznymi fioletowymi kwiatami, zebranymi w koszyczki, kwitnacymi od maja do czerwca. W składzie olejku, otrzymanego $z$ części nadziemnych zidentyfikowano łącznie 72 związki, których 
zawartość wynosiła 91,9\%. Najliczniejszymi grupami zwiazków mieszaniny były węglowodory $(20,3 \%)$, kwasy thuszczowe $(19,8 \%)$, seskwiterpeny węglowodorowe $(9,4 \%)$ i ich tlenowe pochodne $(12,1 \%)$. Składnikami dominującymi były: 4-vinyl gwajakol (8,5\%), kwas palmitynowy $(6,2 \%)$, kwas laurynowy $(5,3 \%)$, heptakozan $(3,9 \%)$ i tlenek kariofilenu $(2,9 \%)$ (SEnatore i współaut. 2005, DITOMASO i współaut. 2013).

Centaurea iconiensis Hub.-Mor. jest endemicznym gatunkiem wieloletnim występującym na terenie Turcji. Łodyga tej rośliny wznosi się na wysokość $60-80 \mathrm{~cm}$, liście sa gładkie, a kwiaty jaskrawo-żółte. Pozyskany z ziela olejek eteryczny wyróżnił się specyficznym składem. Głównym zwiazkiem, stanowiącym aż $84,3 \%$ olejku, okazał się undeken. W mniejszej ilości natomiast występowal $\beta$-kariofilen $(3,4 \%)$ i tlenek kariofilenu (0,5\%) (FLAMini i współaut. 2006).

Centaurea kotschyi var. kotschyi (syn. Centaurea kotschyi (Boiss. \& Heldr.) Hayek (CKK) i Centaurea kotschyi var. decumbens (CKD) należa do sekcji Cheirolepis i maja $10-60 \mathrm{~cm}$ łodyge ze zdrewniałym kłączem, lancetowate liście i żółte kwiaty. Sa to endemiczne rośliny występujące w Turcji. Oba omawiane gatunki różnią się od siebie rodzajem lodygi: C. kotschyi var. kotschyi ma prosta łodygę, czasami lekko zakrzywioną u podstawy, natomiast łodyga C. kotschyi var. decumbens jest płożacca się. Olejki eteryczne pozyskiwane były wyłącznie ze świeżych koszyczków kwiatowych. Łącznie zidentyfikowano w nich 61 składników, stanowiących 91,7\% olejku w przypadku CKD oraz $94,8 \%$ dla CKK. Głównymi składnikami olejku pozyskanego z C. kotschyi var. decumbens były seskwiterpeny, wśród których przeważały: germakren D $(29,4 \%)$, $\beta$-kariofilen $(11,2 \%)$, $\beta$-cedren $(7,1 \%), \quad \beta$-bisabolan $(4,3 \%)$, bicyklogermakren $(4,1 \%)$, a także wiele innych substancji seskwiterpenowych o zawartości od 0,2 do $3 \%$. Olejek eteryczny zawierał również niewielkie ilości różnych aldehydów nieterpenowych. Monoterpeny były nieliczne: a-pinen i $p$-cymen w śladowych ilościach, a także a-felandren i mircen. $\mathrm{W}$ olejku eterycznym pozyskanym z C. kotschyi var. kotschyi seskwiterpeny były również dominujaca grupa składników, z których głównym zwiazkiem był germakren D $(44,2 \%)$, natomiast zawartość $\beta$-kariofilenu $(12,1 \%)$ była porównywalna $z$ C. kotschyi var. decumbens. Olejek zawierał również bicyklogermakren (5,5\%), $\beta$-cedren $(4,3 \%), \beta$-bisabolan $(1,9 \%)$, a także trikozan $(3,6 \%)$, $\beta$-selinen $(3,1 \%)$ i tlenek kariofilenu (3\%). W śladowych ilościach lub w bardzo niskim odsetku występowały również aldehydy nieterpenowe (ERTUGRUL i współaut. 2003).
Centaurea lanigera DC. [syn. Cyanus lanigerus (DC.) Holub.] jest wieloletnim gatunkiem endemicznym dla Turcji. Roślina ta ma 5-10 cm płożąca lub wznoszaca się łodygę, kosmkowate lub nieznacznie owłosione liście, wypustki z licznymi rzęskami i śnieżno-białe kwiaty.

Głównymi składnikami olejku eterycznego, pozyskanego $z$ ziela, na drodze destylacji z para wodna, były germakren D $(43,1 \%)$ i $\beta$-kariofilen $(13,7 \%)$ (FLAMINI i współaut. 2006).

Centaurea mucronifera DC. (syn. Psephellus mucronifer (DC.) Wagenitz.) to wieloletnia roślina należąca do sekcji Psephelloideae. Jest to gatunek endemiczny dla Turcji. Charakteryzuje się zdrewniałym kłączem, prostymi łodygami $(3-40 \mathrm{~cm})$, liśćmi $z$ szarawo-białymi włoskami i kwiatami barwy różowo-fioletowej. Można spotkać ją zazwyczaj w szczelinach skalnych i na wapiennych piargach, w południowej i zachodniej Anatolii. Preferencje ekologiczne tego gatunku pokrywaja się $z$ wymaganiami $C$. chrysantha Wagenitz. W przypadku Centaurea mucronifera DC. materiałem roślinnym do izolacji olejku były świeże koszyczki kwiatowe. W otrzymanym olejku eterycznym zidentyfikowano 76 związów, co stanowiło 90,6\% składu. Głównym składnikiem olejku okazał się germakren D w ilości 29,3\%. Ponadto, zidentyfikowano: bicyklogermakren $\quad(4,8 \%)$, $\beta$-kariofilen $(7,3 \%)$, tlenek kariofilenu $(5,2 \%)$ i $\beta$-eudesmol $(17,4 \%)$. Nieterpenowe aldehydy alifatyczne oraz pochodne aromatyczne benzaldehydu i fenyloacetaldehydu stanowiły 9,2\% olejku eterycznego (DURAL i współaut. 2003).

Centaurea napifolia L. jest rocznym gatunkiem powszechnie występującym na Sycylii. Charakterystyczna roșlinę, $z$ licznymi koszyczkami o fioletowych kwiatach, bardzo często można spotkać dziko rosnaça na pastwiskach lub towarzyszaca przydomowym żywopłotom. W skład badanego olejku eterycznego tego gatunku wchodziło 55 zwiazków, które łacznie stanowiły 95,2\% składu, a dominującymi składnikami, stanowiacymi łącznie $84,1 \%$ składu okazały się węglowodory i kwasy tłuszczowe, $z$ głównym składnikiem - kwasem palmitynowym (14,7\%). Spośród węglowodorów w najwyższym stężeniu występowały: pentakozan $(27,3 \%)$, trikozan $(13,7 \%)$ i heptakozan $(12,1 \%)$ (SENATORE i współaut. 2003).

Centaurea nicaeensis All. (syn. Centaurea sicula L.) znana także, jako „Centaurea nizzarda", jest dziko rosnacca roślina dwuletnia o żółtych kwiatach. Spotykana jest na terenie południowych Włoch. Olejek eteryczny, pozyskany podczas destylacji $\mathrm{z}$ para wodna wysuszonych i pokruszonych koszyczków 
kwiatowych, zebranych w pełnym okresie kwitnienia, był barwy bladożółtej o charakterystycznym zapachu. W jego składzie zidentyfikowanych zostało 46 zwiazków, które stanowiły 92,6\% wszystkich związków. Olejek ten charakteryzował się wysoka zawartością nienasyconych kwasów tłuszczowych $(66,4 \%)$ i weglowodorów $(12,7 \%)$. Kwas palmitynowy (33,5\%) i 9,12-oktadekadienowy $(28,8 \%)$, były głównymi kwasami tłuszczowymi, a spośród 11 węglowodorów obecnych w mieszaninie, najwyższa zawartość wykazały: heptakozan $(3,6 \%)$ i nonakozan $(2,8 \%)$. Wśród seskwiterpenów było 10 weglowodorów $(3,1 \%)$ i 5 zawierajacych tlen (3,1\%). Dominującymi związkami należącymi do tej frakcji okazały się kariofilen $(2,0 \%)$ i tlenek kariofilenu (2,1\%). W składzie olejku eterycznego $z$ C. nicaeensis All. na uwagę zasługuje również obecność tymolu $(2,4 \%)$ i karwakrolu (1,8\%) (SENATORE i współaut. 2008).

Głównymi składnikami olejku uzyskanego $z$ wysuszonych części nadziemnych Centaurea paphlagonica (Bornm.) Wagenitz były: kwas palmitynowy (28,9\%), kwas laurynowy $(22,8 \%)$ i tlenek kariofilenu $(9,2 \%)$. Kwasy tłuszczowe były grupa dominująca (KosE i współaut. 2009).

Centaurea parlatoris Heldr. jest gatunkiem endemicznym dla Sycylii, wysteppujacym na obszarze wulkanu Etna, gór Pelorytańskich i gór Madonie. Roślina ta kwitnie na fioletowo, lokalnie nazywana jest „fiordaliso di Parlatore”. Do otrzymania olejku eterycznego wykorzystano całe kwiaty, zebrane w pełnym okresie kwitnienia. Otrzymany bladożółty olejek, o specyficznym zapachu, zawierał 80 zwiazków, które stanowiły łacznie $91,9 \%$ zawartości. W składzie olejku przeważały głównie węglowodory $(42,0 \%)$ i kwasy tłuszczowe (22,0\%). Dominujacym składnikiem olejku był kwas palmitynowy $(18,1 \%)$, przy stosunkowo niewielkiej ilości kwasu 9,12-oktadekadienowego (2,3\%). Najliczniejszymi składnikami frakcji węglowodorowej, składajacej się z 20 związków, były: nonakozan $(10,2 \%)$, heptakozan $(9,6 \%)$ i trikozan (5,4\%). W olejku wykazano również obecność 19 seskwiterpenów: 9 węlowodorów (3,3\%) i 10 zawierajacych tlen (8,4\%). W grupie tej dominujacymi zwiazkami były kariofilen (2,6\%) i tlenek kariofilenu (4,4\%) (SENATORE i współaut. 2008).

Centaurea pelia DC. jest greckim gatunkiem endemicznym. Jest to bylina o stosunkowo niewielkich koszyczkach i kwiatach barwy żółtej. Do otrzymania olejku eterycznego wykorzystano świeże nadziemne części roślin, zebrane w pełnym okresie kwitnienia. W skład olejku wchodziło wiele związków, jednak grupa wyróżniającą się dużą zawartościa okazały się węglowodory i ich tlenowe pochodne $(31,4 \%)$, spośród których heptakozan $(5,7 \%)$ był zwiazkiem o najwyższym stężeniu. W znaczącej ilości obecne były także kwasy tłuszczowe (31,9\%), wśród których dominowały: kwas palmitynowy (15,4\%), kwas dodekanowy $(7,9 \%)$ i kwas tetradekanowy $(4,2 \%)$. Warto również wspomnieć o seskwiterpenach tlenowych, wśród których dominujacymi były tlenek kariofilenu (4,3\%) i spatulenol (2,1\%) (LAZARI i współaut. 2000).

Centaurea pseudoscabiosa Boiss. \& Bushe jest to gatunek sekcji Acrocentron, który spotkać można głównie w obszarze wschodniej Anatolii. Roślina ta, należąca do gatunków termofilnych, preferuje lasy cedrowe lub jodłowe, a także półsuchy, wilgotny klimat śródziemnomorski $z$ opadami rocznymi około $650 \mathrm{~mm}$. Analiza olejku eterycznego, pozyskanego $z$ części nadziemnych, wykazała obecność 55 związków stanowiących łącznie $86,6 \%$ składu olejku. Kompozycja okazała się uboga w monoterpeny, które obecne były tylko w śladowych ilościach, $z$ wyjątkiem tymolu $(0,3 \%)$ i linalolu $(0,2 \%)$. Wśród wielu składników lotnych znalazły się aldehydy nieterpenowe, alkohole, ketony $i$ węglowodory nienasycone, jednak również w niskim odsetku. Najliczniejszą grupa składników olejku eterycznego okazały się seskwiterpeny, a wśród nich w dużej ilości występowały: germakren D (36\%), $\beta$-seskwifelandren $(8,5 \%), \beta$-kariofilen $(8,1 \%)$, tlenek kariofilenu $(4,4 \%)$, bicyklogermakren $(4,2 \%)$ i spatulenol $(2,8 \%)$ (Flamini i współaut. 2002).

Centaurea ptosimopappoides Wagenitz jest wieloletnim półkrzewem o prostych wzniesionych (do $35 \mathrm{~cm}$ ) pędach. Roślina ta ma twarde, nagie liście, ostro zakończone wypustki i żółte kwiaty. Jest to gatunek endemiczny dla Turcji. Do najważniejszych związków występujących w olejku eterycznym, pozyskanym $z$ ziela należały: germakren D $(36,9 \%)$ i $\beta$-kariofilen $(22,5 \%)$ (FLAMINI i współaut. 2006).

Centaurea pulcherrima Willd. var. pulcherrima [syn. Psephellus pulcherrimus (Wild.) Wagenitz] to gatunek roślinności alpejskiej, wzrastajacy na terenach skalistych. Jest to wieloletnia roślina tworzaca keppy, charakteryzująca się różowymi kwiatami. Olejek eteryczny ze świeżych kwiatów tego gatunku pozyskiwany był za pomoca dwóch metod: destylacji z para wodna (HD) i destylacji mikrofalowej (MD). W składzie otrzymanych olejków otrzymanych tymi metodami zidentyfikowano łaccznie 58 oraz 57 zwiąków, które stanowiły odpowiednio 93,7\% i 91,6\% składu. Olejek uzyskany w procesie destylacji mikrofalowej różnił się od otrzymanego podczas destylacji $z$ para wodna składem ilościowym i nieznacznie jakościowym. Związkami dominującymi w przypad- 
ku obu olejków okazały się: germakren D (17,8\% HD, 23,2\% MD), limonen (3,5\% HD, 2,6\% MD), linalol (3,3\% HD, 2,9\% MD), $\beta$-kariofilen $(5,4 \% \mathrm{HD}, 6,4 \% \mathrm{MD})$, bicykloelemen $(2,1 \% \mathrm{HD}, 3,5 \% \mathrm{MD})$ i a-kadinol $(5,8 \%$ $\mathrm{HD} ; 4,4 \% \mathrm{MD})$. Omawiane olejki wykazują właściwości przeciwbakteryjne, co zostało potwierdzone badaniami in vitro, metoda rozcieńczeń $\mathrm{w}$ agarze. Testy wykazały, że olejek eteryczny pozyskany $z \quad C$. pulcherrima Willd. var. pulcherrima charakteryzuje się dobra aktywnościa przeciwbakteryjną w stosunku do bakterii Gram-dodatnich, zwłaszcza Mycobacterium smegmatis, oraz grzybów drożdżopodobnych Candida albicans, jednak działa słabo na bakterie Gram-ujemne (KAHRIMAN i współaut. 2012).

Olejek eteryczny z ziela Centaurea pullata L. zawierał 75 zwiazków, z których siedem było nieznanych. Składniki kompozycji stanowiły łacznie 96,2\% olejku. Wśród wyizolowanych związków, dominujacymi okazały się: tlenek kariofilenu $(27,0 \%), 6,10,14$-trimetylo-2-pentadekanon (14,9\%) i izomer fitolu $(16,5 \%)$. W ilościach znaczacych obecne były również: pentadekan $(2,0 \%), \beta$-eudesmol $(1,7 \%)$ i $\beta$-kariofilen $(1,6 \%)$, a także 15 innych, ważnych składników, jak na przykład a-pinen, terpinen-4-ol, piperyton, tetrakozan, znaleziono w ilościach śladowych $(<0,1 \%)$ (DoB i współaut. 2009).

Centaurea reuteriana var. reuteriana $(\mathrm{Bo}-$ iss.) Dostál [syn. Cyanus reuterianus (Boiss.) Holub] należy do sekcji Cyanus i jest roślina endemiczna dla Turcji. Z olejku eterycznego, pozyskanego $\mathrm{w}$ procesie mikrodestylacji nadziemnych, wysuszonych części roślin, wyizolowano 62 zwiazki, które stanowiły łacznie $84,2 \%$. W składzie olejku, dominujaca grupa były kwasy tłuszczowe i estry $(32,3 \%)$, gdzie głównym zwiazkiem był kwas palmitynowy $(23,8 \%)$. Ponadto, dużym stężeniem wyróżniły się: karwakrol (14,9\%), tlenek kariofilenu $(6,2 \%)$, heptakozan $(4,7 \%)$ i nonakozan (4,3\%) (KARAMENDERES i współaut. 2008).

Centaurea saligna (K. Koch) Wagenitz jest gatunkiem endemicznym występujacym w Turcji. W składzie olejku zidentyfikowano 40 związków, stanowiacych 84,2\% składu, spośród których najliczniejszą grupa okazały się seskwiterpeny tlenowe $(14,6 \%)$. Do głównych składników olejku należały: kwas palmitynowy $(41,9 \%)$, fitol $(8,2 \%)$, heptakozan $(5,2 \%)$ i karwakrol (4,1\%) (ALTINTAS i współaut. 2009).

Centaurea sessilis Wild. (syn. Centaurea oltensis Sosn.) to gatunek występujacy wyłącznie w Turcji, rozmieszczony głównie na terenie wschodniej Anatolii. Jest to zielna roślina wieloletnia, rosnaca na górskich stokach i suchych stanowiskach. Głównymi składnikami olejku eterycznego, otrzymane- go $z$ wysuszonych nadziemnych części roślin spośród 40 wyizolowanych, stanowiacych łącznie $66,7 \%$ olejku były: $\beta$-eudesmol $(12,4 \%)$, tlenek kariofilenu $(10 \%)$, fitol $(6,4 \%)$, spatulenol $(4,9 \%)$ i $6,10,14$-trimethyl-2-pentadekanon (3,1\%) (YAYLI i wspó1aut. 2005).

Centaurea solstitialis L. ssp. schouwii (DC.) Gugler jest gatunkiem endemicznym dla Sycylii i Sardynii. Jest to roślina roczna lub dwuletnia, posiadajaca żółte, hermafrodytyczne kwiaty. Przypisuje się jej właściwości allelopatyczne i neurotoksyczne. Bladożółty olejek eteryczny otrzymano $z$ wysuszonych i pokruszonych koszyczków kwiatowych. Analiza otrzymanego olejku wykazała obecność 57 zwiąków, stanowiacych $91,8 \%$ mieszaniny. Kwasy tłuszczowe i ich estry $(43,6 \%)$ oraz trzynaście zwiazków węglowodorowych $(28,0 \%)$ były przeważajacymi frakcjami olejku. Głównym kwasem tłuszczowym, który występował również w postaci estru metylowego (3,9\%), był kwas palmitynowy $(29,4 \%)$; w znacznym stężeniu wykryto również kwas 9,12-oktadekadienowy (4,9\%). Spośród węglowodorów, najbardziej wyróżniajacymi się substancjami były: heptakozan $(7,7 \%)$, nonakozan $(5,6 \%)$ i pentakozan $(5,2 \%)$. W olejku tym znaczaca grupa okazały się również seskwiterpeny, które reprezentowane były przez 18 związków: 12 węglowodorów $(5,2 \%)$ oraz 6 zawierajacych tlen $(2,5 \%)$. Germakren D $(1,7 \%)$, tlenek kariofilenu $(1,5 \%)$ i kariofilen $(1,2 \%)$ były zwiazkami dominujacymi (SENATORE i współaut. 2008).

Centaurea sphaerocephala L. jest wieloletnia roślina trawiasta, dziko rosnaca na Sycylii, lokalnie nazywana "fiordaliso delle spiagge", czyli "chaber plażowy", dorastajacca do $50 \mathrm{~cm}$ wysokości, a jej okres kwitnienia trwa od czerwca do września. Ze świeżych koszyczków kwiatowych, otrzymano olejek eteryczny o bladożółtej barwie, bez specyficznego zapachu. Analiza wykazała, że głównymi grupami zwiazków występujących w składzie olejku były kwasy tłuszczowe (44,2\%) i węglowodory $(15,9 \%)$, a zwiazkami dominujaccymi okazały się: kwas palmitynowy $(30,7 \%)$ i heptakozan $(4,9 \%)$. W skład olejku eterycznego wchodziły także seskwiterpeny (13 węglowodorów; 9,2\%) i seskwiterpeny zawierajace tlen (9 składników; 13,6\%). Spośród seskwiterpenów, do głównych zwiąków wyizolowanych $z$ olejku należały: $\beta$-eudesmol $(5,4 \%)$, humulen epoksydowy II $(1,8 \%)$ i tlenek aromadendrenu II $(1,7 \%)$ (SENATORE i współaut. 2006).

Centaurea thessala subp. drakiensis (Freyn \& Sint.) T. Georgiadis to wieloletnia roślina endemiczna dla Grecji. Gatunek ten ma niewielkie koszyczki i różowo-fioletowe 
kwiaty rurkowate. W składzie olejku otrzymanego $z$ części nadziemnych dominował związek zaliczany do grupy węglowodorów i ich tlenowych pochodnych $(49,7 \%)$, heksakozan, którego stężenie wynosiło 22,6\%. W stosunkowo wysokim stężeniu występowały dwa inne zwiąki należace do tej grupy: dokozan $(5,5 \%)$ i triakontan $(5,3 \%)$. Olejek zawierał również w znacznej ilości tlenek kariofilenu $(7,8 \%)$ i spatulenol $(5,8 \%)$, należące do seskwiterpenów tlenowych. Kwasy tłuszczowe stanowiły łacznie 13\% olejku, a w najwyższym stężeniu występowały: kwas palmitynowy $(7,4 \%)$ i kwas tetradekanowy (2,1\%) (LAZARI i współaut. 2000).

Centaurea urvillei DC jest gatunkiem należacym do sekcji Acrocentron, występujacym powszechnie. W Turcji uznana jest za roślinę żywicielska dla Phytoecia behen, chrzaszcza $z$ rodziny Cerambycidae (DoB I WSPÓŁAUT. 2009, KIERZEK 2015). W olejku eterycznym otrzymanym $z$ części nadziemnych zidentyfikowano 77 związków, stanowiących łacznie 86,3\% składu. Dominująca grupa w mieszaninie okazały się kwasy tłuszczowe i estry (44,6\%), w których zwiąkami głównymi były: kwas palmitynowy $(26,4 \%)$, kwas dodekanowy $(9,4 \%)$ i kwas tetradekanowy (4,1\%). Znacznym stężeniem wyróżnił się również karwakrol (12,4\%) (KARAMENDERES i współaut. 2008).

Ostatnią o omawianych roślin jest Centaurea zuccariniana DC., dwuletni gatunek występujacy głównie na obszarze Grecji i południowej Albanii. Roślina ta kwitnie na fioletowo i charakteryzuje się stosunkowo małymi koszyczkami kwiatowymi. Pozyskany $z$ części nadziemnych, pozbawiony specyficznego zapachu bladożółty olejek charakteryzuje się wysoka zawartościa węglowodorów $i$ ich tlenowych pochodnych, stanowiących łącznie $27,4 \%$ olejku, oraz kwasów tłuszczowych, których stężenie wyniosło 17,3\%. Do związków dominujacych zaliczamy kwasy: palmitynowy $(6,5 \%)$, tetradekanowy $(4,1 \%)$ i heptakozan $(4,0 \%)$. W składzie olejku, dość dużym stężeniem wyróżnił się tlenek kariofilenu $(6,2 \%)$ i spatulenol $(4,2 \%)$, należące do grupy seskwiterpenów tlenowych (LAZARI i współaut. 2000).

Olejki eteryczne roślin $z$ rodzaju Centaurea L. stanowią mieszaniny różnorodnych związków. Każdy $z$ nich ma osobliwy i niepowtarzalny skład, niekiedy wyróżniajacy się na tle pozostałych zawartościa unikatowych substancji, jednakże cechuje je również duże podobieństwo. Analizując skład mieszanin olejkowych opisanych gatunków rodzaju Centaurea L., wyraźnie zauważa się obecność związków seskwiterpenowych jako grupy dominującej, przy czym przeważaja w niej zwiazki węlowodorowe, a w mniej- szej ilości ich tlenowe pochodne. Zwiąkami dominującymi, najczęściej występującymi w składzie tych olejków i stanowiącymi najwyższą zawartość procentową są: germakren D, $\beta$-kariofilen, bicyklogermakren, tlenek kariofilenu, spatulenol. W mniejszych ilościach wystepują: $\beta$-eudesmol, $\beta$-bisabolan, $\beta$-selinen, $\beta$-cedren. W składzie olejków obecne były również monoterpeny, jednak przeważnie w ilości nieprzekraczającej $1 \%$. Wśród nich najczęściej spotykanymi były: a- i $\beta$-pinen, mircen, a-fellandren, $p$-cymen, limonen i o-cymen. W przypadku sporej grupy roślin, w kompozycji pozyskanych $z$ nich olejków dominują kwasy tłuszczowe, na czele $z$ kwasem palmitynowym. Innymi, wspólnie wyizolowanymi zwiazkami były nieterpenowe pochodne takie jak: aldehydy alifatyczne, alkohole, ketony, estry, węglowodory, fenole. Spośród nich na uwage zasługuja: karwakrol, tymol, fitol, oktanal, dekanal i heptakozan. Skład chemiczny opisanych olejków przedstawiono w Tabeli 1.

Warto zwrócić uwage, iż skład olejków pozyskiwanych $z$ poszczególnych roślin różni się w zależności od ich pochodzenia. Widoczne są niekiedy dość duże różnice w wydajności, składzie chemicznym i zwiazkach dominujacych, co dzieli rodzaj Centaurea L. na wiele chemotypów. Relacja ta zwiazana jest $z$ różnymi siedliskami roślin i może wynikać $z$ odmiennych warunków środowiskowych takich jak: opady, skład gleby czy struktura morfologiczna, aczkolwiek wnioski takie wymagaja dalszych badań (DoB i współaut. 2009).

\section{ZASTOSOWANIE}

Niektóre gatunki Centaurea L., ze względu na atrakcyjne kwiaty, uprawiane sa jako rośliny ozdobne, inne maja ważne zastosowania lecznicze. Badania etnofarmakologiczne wykazały, że wiele $z$ tych roślin jest w różnych krajach używana w medycynie ludowej do leczenia różnych dolegliwości. Niektóre gatunki, takie jak Centaurea cyanus L. (syn. Cyanus segetum Hill.) lub Centaurea scabiosa L., wykazuja działanie przeciwbólowe, przeciwgoraczkowe oraz kardiotoniczne i sa stosowane w schorzeniach wątroby, skóry, a także w łagodzeniu dolegliwości żołądkowych. Natomiast między innymi Centaurea solstitilalis L. w tureckiej medycynie ludowej wykorzystywana jest do leczenia ropni, hemoroidów, wrzodów i przeziębienia. W literaturze naukowej możemy znaleźć również wzmianki o właściwościach przeciwłupieżowych, przeciwbiegunkowych, przeciwreumatycznych, przeciwzapalnych, żółciopędnych, diuretycznych, cytotoksycznych, a także 
Tabela 1. Główne składniki olejków eterycznych poszczególnych gatunków rodzaju Centaurea L.

\begin{tabular}{|c|c|}
\hline Gatunek & Główne składniki olejku \\
\hline C. aladagensis Wagenitz & kwas palmitynowy, tlenek kariofilenu \\
\hline C. antiochia Bioss. & germakren $\mathrm{D}, \beta$-kariofilen, spatulenol, dekanal \\
\hline C. antitauri Hayek & germakren $\mathrm{D}, \beta$-kariofilen \\
\hline C. appendicigera K. Koch & tlenek kariofilenu, $\beta$-kariofilen \\
\hline C. armena Boiss. & $\beta$-eudesmol, $\beta$-kariofilen, kalaren \\
\hline C. aucheri (DC) Wagenitz & tlenek kariofilenu, $\beta$-kariofilen, germakren $\mathrm{D}$ \\
\hline C. babylonica (L.) L. & germakren $\mathrm{D}, \beta$-kariofilen \\
\hline C. balsamita Lam. & germakren $\mathrm{D}$, spatulenol, $\beta$-kariofilen \\
\hline C. cadmea Boiss. & kwas palmitynowy, karwakrol, kwas dodekanowy, fitol \\
\hline C. calcitrapa $\mathrm{L}$. & $\begin{array}{l}\text { kwas 9,12-oktadekadienowy, trikozan, kariofilen, } \beta \text {-bisabolen, ger- } \\
\text { makren D }\end{array}$ \\
\hline C. calolepis Boiss. & $\begin{array}{l}\text { kwas palmitynowy, karwakrol, fitol, spatulenol, } \\
\text { kwas tetradekanowy }\end{array}$ \\
\hline $\begin{array}{l}\text { C. cariensis Boiss. } \\
\text { subsp. maculiceps (O. Schwarz) Wagenitz }\end{array}$ & karwakrol, kwas dodekanowy, kwas palmitynowy \\
\hline $\begin{array}{l}\text { C. cariensis Boiss. } \\
\text { subsp. microlepis (Boiss.) Wagenitz }\end{array}$ & karwakrol, kwas dodekanowy, kwas palmitynowy, fitol \\
\hline C.cheirolepidoides Wagenitz & germakren $\mathrm{D}, \beta$-kariofilen, tlenek kariofilenu \\
\hline C. chrysantha Wagenitz. & $\begin{array}{l}\text { germakren } \mathrm{D} \text {, bicyklogermakren, } \beta \text {-kariofilen, } \\
\text { tlenek kariofilenu }\end{array}$ \\
\hline $\begin{array}{l}\text { C. cineraria L. } \\
\text { subsp. umbrosa (Lacaita) Pign }\end{array}$ & $\begin{array}{l}\text { germakren D, kariofilen, tlenek kariofilenu, } \\
\text { kwas palmitynowy }\end{array}$ \\
\hline C. cuneifolia Sibth. \& Sm. & $\begin{array}{l}\beta \text {-eudesmol, kwas palmitynowy, spatulenol, } \\
\text { tlenek kariofilenu }\end{array}$ \\
\hline C. cyanus $\mathrm{L}$. & karwakrol, kwas palmitynowy, tlenek kariofilenu \\
\hline C. deflexa Wagenitz & germakren $\mathrm{D}$, tlenek kariofilenu \\
\hline C. depressa Bieb. & kwas palmitynowy, karwakrol, kwas tetradekanowy, kwas dodekanowy \\
\hline C. dichroa Boiss. \& Heldr & kwas palmitynowy, tlenek kariofilenu, spatulenol \\
\hline C. ensiformis P.H. Davis & karwakrol, kwas palmitynowy, fitol, heptakozan, tlenek kariofilenu \\
\hline C. eryngioides Lam. & kwas palmitynowy, $\beta$-eudesmol, tlenek kariofilenu \\
\hline C. euxina Velen. & kwas palmitynowy, spatulenol, fitol, tlenek kariofilenu, $\beta$-eudesmol \\
\hline $\begin{array}{l}\text { C. hadimensis Wagenitz K. Ertugrulb \& } \\
\text { H. Dural }\end{array}$ & $\begin{array}{l}\text { germakren D, } \beta \text {-kariofilen, spatulenol, tlenek kariofilenu, bicykloger- } \\
\text { makren }\end{array}$ \\
\hline $\begin{array}{l}\text { C. helenioides Boiss \& Hausskn. } \\
\text { ex Boiss }\end{array}$ & tlenek kariofilenu, germakren D \\
\hline C. hierapolitana Boiss. & kwas palmitynowy, karwakrol, kwas tetradekanowy \\
\hline C. huber-morathii Wagenitz & oktanol, kwas palmitynowy, tlenek kariofilenu, $p$-cymen \\
\hline $\begin{array}{l}\text { C. iberica Trev. ex Spreng. } \\
\text { var. hermonis Boiss. Lam }\end{array}$ & $\begin{array}{l}\text { 4-vinyl gwajakol, kwas palmitynowy, kwas laurynowy, heptakozan, } \\
\text { tlenek kariofilenu }\end{array}$ \\
\hline C. iconiensis Hub..-Mor. & $\beta$-kariofilen, tlenek kariofilenu \\
\hline C. kotschyi (Boiss. \& Heldr.) Hayek & germakren $\mathrm{D}, \beta$-kariofilen, $\beta$-cedrene, $\beta$-bisabolan, bicyklogermakren \\
\hline C. lanigera DC. & germakren $\mathrm{D}, \beta$-kariofilen \\
\hline C. mucronifera DC. & $\begin{array}{l}\text { germakren } \mathrm{D} \text {, bicyklogermakren, } \beta \text {-kariofilen tlenek kariofilenu, } \\
\beta \text {-eudesmol }\end{array}$ \\
\hline
\end{tabular}




\author{
C. napifolia L. \\ C. nicaeensis All. \\ C. paphlagonica (Bornm.) Wagenitz \\ C. parlatoris Helder \\ C. pelia DC. \\ C. pseudoscabiosa Boiss. \& Bushe \\ C. ptosimopappoides Wagenitz \\ C. pulcherrima Willd. \\ var. pulcherrima \\ C. pullata L. \\ C. reuteriana Boiss. \\ var. reuteriana (Boiss.) Dostál \\ C. saligna_(K. Koch) Wagenitz \\ C. sessilis Wild. \\ C. solstitialis $\mathrm{L}$. \\ ssp. schouwii (DC.) Gugler \\ C. sphaerocephala L. \\ C. thessala Hausskn. subp. drakiensis \\ (Freyn \& Sint.) T. Georgiadis \\ C. urvillei DC. \\ C. zuccariniana DC.
}

kwas palmitynowy, pentakozan, trikozan, heptakozan

kwas palmitynowy, kwas 9,12-oktadekadienowy, kariofilen, tlenek kariofilenu, tymol, karwakrol

kwas palmitynowy, kwas laurynowy, tlenek kariofilenu

kwas palmitynowy, nonakozan, trikozan, heptakozan, kariofilen, tlenek kariofilenu

kwas palmitynowy, kwas dodekanowy, heptakozan, tlenek kariofilenu, spathulenol

germakren $\mathrm{D}, \beta$-seskwifelandren, $\beta$-kariofilen, tlenek kariofilenu, bicyklogermakren, spatulenol

germakren $\mathrm{D}, \beta$-kariofilen

germakren D, limonen, linalol, $\beta$-kariofilen, a-cadinol, bicykloelemen,

tlenek kariofilenu, izomer fitolu, $\beta$-eudesmol, 6,10,14-trimetylo-2- pentadekanon, pentadekan, $\beta$-kariofilen

karwakrol, tlenek kariofilenu, heptakozan, nonakozan

kwas palmitynowy, fitol, heptakozan, karwakrol

$\beta$-eudesmol, tlenek kariofilenu, fitol, spatulenol

kwas palmitynowy, kwas 9,12-oktadekadienowy, heptakozan, nonakozan, pentakozan, germakren $\mathrm{D}$, tlenek kariofilenu, kariofilen

kwas palmitynowy, heptakozan, $\beta$-eudesmol

heksakozan, tlenek kariofilenu, spatulenol, kwas palmitynowy

kwas palmitynowy, karwakrol, kwas dodekanowy, kwas tetradekanowy kwas palmitynowy, tlenek kariofilenu, spatulenol przeciwbakteryjnych gatunków $z$ tego rodzaju (AKTUMSEK i współaut. 2011).

Bogaty skład olejków eterycznych $z$ rodzaju Centaurea L., skłania do dokładnego sprawdzenia ich aktywności biologicznej i wpływu na organizmy żywe. Zawartość w olejkach różnorodnych składników, które często wykazuja podobne działanie, świadczy o możliwości ich synergistycznego działania. Przeprowadzone badania potwierdzaja niektóre $z$ przewidywanych efektów, jak działanie: przeciwbakteryjne i przeciwgrzybicze, antyoksydacyjne, przeciwzapalne, cytotoksyczne, hipoglikemiczne $i$ antycholinoesterazowe (EREL i współaut. 2011, POLITEO i współaut. 2012, ZENGIN i współaut. 2012, ERTAS I WSPÓŁAUT. 2014). Najistotniejsza funkcją olejków eterycznych $z$ rodzaju Centaurea L. jest ich hamujacy wpływ na rozwój mikroorganizmów: bakterii G-dodatnich i G-ujemnych oraz grzybów. Różnice w aktywności przeciwdrobnoustrojowej poszczególnych olejków wynikają $z$ odmiennego składu chemicznego i różnego stężenia związków odpowiadających za te właściwości. Testy wykazały lepsze działanie przeciwbakteryjne w stosunku do bakterii Gram-dodatnich, niż do Gram-ujemnych. Właściwości przeciwbakteryjne próbek, badane sa zazwyczaj poprzez zastosowanie metody dyfuzji na krażku lub mikrorozcieńczania. Przykładowo, olejki eteryczne $z \quad C$. sessilis Wild. i C. armena Boiss. wykazuja aktywność przeciwbakteryjna w stosunku do Yersinia pseudotuberculosis, Enterococcus faecalis, Staphylococcus aureus i Bacillus subtilis. Również olejki eteryczne z C. jacea L. i C. pannonica (Heuff.) Hayek przejawiają znaczacą aktywność przeciwbakteryjna, szczególnie w stosunku do bakterii G-dodatnich. Podane przykłady aktywności przeciwdrobnoustrojowej olejków Centaurea L. to niewielka część spośród licznych testów potwierdzajacych ich działanie w stosunku do mikroorganizmów. Właściwości te zwiazane sa $z$ występowaniem w olejkach zwiazków takich jak karwakrol, eugenol, tymol, tlenek kariofilenu, $\beta$-kariofilen czy $\beta$-eudesmol, które działaja $w$ synergii $z$ innymi składnikami, takimi jak: aldehydy, alkohole czy terpeny (1-okten-3-ol, linalol, limonen, $p$-cymen). 
Mimo że związki te obecne sa $\mathrm{w}$ badanych olejkach nieraz tylko w ilościach śladowych, to okazuje się, że sa one bardzo aktywne w stosunku do różnych drobnoustrojów (YAYLI i współaut. 2005, FORMISANO i współaut. 2008, Milosević i współaut. 2010, Politeo i współaut. 2012). Dominująca w składzie olejków obecność seskwiterpenów laktonowych jest czynnikiem warunkującym ich przeciwzapalne, a także cytotoksyczne właściwości. Aktywność przeciwzapalna potwierdzona została badaniami czynności biologicznej olejków pozyskiwanych $\mathrm{z}$ gatunków takich jak, między innymi, C. calolepis Boiss., C. iberica Trev. ex Spreng, C. cadmea Boiss., czy C. hierapolitana Boiss. W przypadku C. calolepis Boiss. stwierdzono, że zawarty $\mathrm{w}$ niej seskwiterpen laktonowy wykazuje umiarkowana toksyczność w stosunku do chondrocytów i makrofagów, co potwierdza jego działanie cytotoksyczne. Wykazano także, że obecne w składzie olejków przeciwutleniacze moga częściowo przyspieszać gojenie sie ran, przez wychwytywanie wolnych rodników tlenowych, wytwarzanych uszkodzonej tkance. Właściwości antyoksydacyjne wynikaja przede wszystkim $\mathrm{z}$ obecności $\mathrm{w}$ olejkach zwiazków fenolowych oraz terpenowych, co potwierdziły liczne testy przeprowadzane $z$ użyciem olejków pozyskiwanych z różnych gatunków Centaurea L.: np. C. balsamita Lam. (syn. Stizolophus balsamita (Lam.) K. Koch) i C. iberica Trev. ex Spreng. var. hermonis Boiss. Lam.), wykazuja umiarkowane działanie hamujace wobec enzymów: acetylocholinoesterazy i butyrylocholinesterazy (KOCA i współaut. 2009, EREL i współaut. 2011, AKTUMSEK i współaut. 2013, ERTAS i współaut. 2014).

W badaniach aktywności biologicznej uwzględniono także działanie pojedynczych substancji, dominujących w składzie olejków eterycznych. Uważa się, że należący do seskwiterpenów germakren D ma właściwości owadobójcze, szczególnie w stosunku do komarów, działanie odstraszające mszyce i kleszcze, ale również pełni funkcje feromonu i zwiększa atrakcyjność roślin (SCHMIDT i współaut. 1998, MOZURAITIS i współaut. 2002, NOGE i BECERRA 2009). $\beta$-kariofilen (BCP) wraz $\mathrm{z}$ a-kariofilenem oraz tlenkiem kariofilenu tworzy mieszaninę znana jako kariofilen. $\beta$-kariofilen jest węglowodorem seskwiterpenowym o budowie dwucyklicznej. Badania przeprowadzone na myszach, potwierdzaja czynność anksjolityczna i przeciwdepresyjna $\mathrm{BCP}$, który wiąże się selektywnie $z$ receptorem CB2 (receptor kannabinoidowy typu 2), działajacc analogicznie do związków kannabinoidowych. Warto zwrócić uwage, na brak powinowactwa do receptorów CB1 (receptor kannabinoidowy typu 1), dzięki cze- mu zwiazek ten nie wywołuje efektów psychotropowych. Receptory CB1 rozmieszczone sa np. w tkance tłuszczowej mózgu, mięśniach szkieletowych, wątrobie, a CB2 głównie na komórkach układu immunologicznego. Oba typy receptorów składaja się $z$ pojedynczych łańcuchów polipeptydowych i sa częścia układu endokannabinoidowego (PIETRZAK i współaut. 2011). Właściwości te daja możliwość wykorzystania BCP jako skutecznego środka przeciwdepresyjnego, rownież ze wzgędu na duża tolerancje $i$ bezpieczeństwo stosowania u ludzi oraz brak toksyczności. Związek ten przejawia aktywność przeciwzapalna, antyoksydacyjna i przeciwnowotworową. Ponadto wykazuje również działanie przeciwbólowe i silnie miejscowo znieczulające (GHELARDINI i współaut. 2001, BAHI i współaut. 2014). Tlenek kariofilenu znany jest jako środek konserwujący żywność, leki i kosmetyki oraz został uwzględniony przez Radę Europejska w wykazie naturalnych i syntetycznych substancji aromatyzujacych. Podobnie jak $\beta$-kariofilen, charakteryzuje się aktywnościa przeciwzapalna $i$ przeciwnowotworową. Wykazuje on również działanie wspomagające regenerację skóry i właściwości przeciwgrzybicze, porównywalne do działania cyklopiroksolaminy, potwierdzone w badaniach na dermatofitach. Duża zaleta tego związku jest brak działania toksycznego, bezpieczeństwo i niski potencjał alergizujacy (YANG i współaut. 1999, CHAVAN i współaut. 2010). Kwas palmitynowy, inhibitor fosfolipazy A2, ma właściwości emulgujace i działanie przeciwzapalne. Stosowany w preparatach kosmetycznych, dzięki właściwościom okluzyjnym (właściwości błonotwórcze), wspomaga utrzymanie prawidłowego nawilżenia skóry. Zjawisko okluzji polega na wytworzeniu na skórze warstwy, która wyraźnie zmniejsza, a nawet uniemożliwia odparowanie wody z naskórka (MOLSKI 2012, VASUDEVAN i współaut. 2012). Badania in vitro wykazały, że spatulenol, alkohol seskwiterpenowy, hamuje aktywność glikoproteiny $\mathrm{P}$ przyczyniającej się do wystapienia zjawiska oporności wielolekowej (MDR), przez co może być wykorzystany jako składnik leków stosowanych $\mathrm{w}$ chemioterapii. Zwiazek ten wykazuje również właściwości immunosupresyjne (LAZARI i współaut. 2000). Karwakrol (izomer tymolu), inhibitor wzrostu mikroorganizmów, ma działanie przeciwbakteryjne w stosunku do wielu patogenów pokarmowych oraz właściwości przeciwgrzybicze, a także wykazuje aktywność przeciwzapalna, przeciwnowotworowa, antygenotoksyczna, przeciwbólową i hepatoprotekcyjna (YANISHLIEVA i współaut. 1999, BAGAMBOULA i współaut. 2004, BASER 2008). $\beta$-eudesmol to alkohol seskwiterpenowy, któremu przypisuje się 
zdolność hamowania angiogenezy, co może wspomóc rozwój leków w terapii chorób $z$ nią zwiazanych, w szczególności chorób nowotworowych. Ponadto, zwiazek ten wykazuje aktywność przeciwdrgawkowa, antymutagenna, przeciwgrzybicza i może być wykorzystany w leczeniu otępienia (CHIOU i współaut. 1997, YU i współaut. 2008).

Właściwości pojedynczych substancji oraz olejków eterycznych wyizolowanych $z$ roślin rodzaju Centaurea L. dowodza, że ze względu na bardzo dobra aktywność przeciwdrobnoustrojowa, mogą one pełnić rolę naturalnych środków przeciwbakteryjnych czy antyseptycznych. Będąc źródłem antybiotyków naturalnych, szczególnie przeciw bakteriom opornym na antybiotyki syntetyczne, moga stanowić bazę do tworzenia nowych leków wykorzystywanych w leczeniu chorób zakaźnych. Szczególnie istotne dla przemysłu farmaceutycznego sa także właściwości przeciwzapalne i antyoksydacyjne, co w połaczeniu $z$ aktywnością przeciwdrobnoustrojowa daje szanse na wykorzystanie ich w wielu preparatach antyseptycznych, odkażających i przyspieszajacych gojenie ran. Należy jednak zwrócić uwage na aktywność cytotoksyczna niektórych substancji, wchodzących w skład mieszanin olejkowych, które moga oddziaływać niekorzystnie na organizm ludzki, wywołując np. alergie kontaktowe, czy też dzialanie hepato-, nefro- czy neurootoksyczne. Stąd ogromne znaczenie ma poznanie szczegółowe składu poszczególnych mieszanin, które moga być wykorzystywane potencjalnie w lecznictwie. Wzrost zainteresowania klientów naturalnymi dodatkami do żywności, kosmetyków i leków zwiększa zapotrzebowanie na naturalne przeciwutleniacze, co daje kolejna możliwość zastosowania olejków eterycznych. Zawarte w nich zwiazki dominujace wykazuja także wiele innych obiecujacych właściwości, dających nadzieję na wykorzystanie w wielu gałęziach przemysłu. Obecnie sa to jednak tylko przypuszczenia, które wymagaja potwierdzenia licznymi badaniami.

\section{PODSUMOWANIE}

Niniejsza praca ma na celu przybliżenie składu, właściwości i zastosowania olejków eterycznych roślin $z$ rodzaju Centaurea L. Jest to bardzo obszerny i zróżnicowany pod względem morfologicznym rodzaj, wcią̇ wymagajacy badań, które pozwola na odpowiednie pogrupowanie gatunków do niego należacych.

Pomimo dużego podobieństwa w wyglądzie zewnętrznym gatunków zaliczane do rodzaju Centaurea L., różnią się one znacząco pod względem składu chemicznego, co oczywiście wpływa na odmienny skład pozyski- wanych $z$ nich olejków. Na różnice te wpływ ma także środowisko w jakim wzrastają. Różnorodność geograficzna występowania gatunków warunkuje więc różnice w wydajności, składzie chemicznym i zawartości głównych zwiąków olejków eterycznych. Olejki te wykazuja również wiele podobieństw, zwłaszcza ze względu na zawartość seskwiterpenów, jako związków głównych, które w szczególności determinuja ich właściwości. Analizujacc związki dominujące w ich składzie stwierdzono, że germakren D, tlenek kariofilenu, $\beta$-kariofilen, a także kwas palmitynowy, spatulenol, karwakrol i $\beta$-eudesmol, sa substancjami najczęściej występującymi. Można zatem wywnioskować, że to w szczególności te substancje, wspomagane przez liczne zwiazki towarzyszace, warunkuja szerokie spectrum działania olejków. Nie dziwi więc, że gatunki rodzaju Centaurea L. przez lata znajdowały zastosowanie w medycynie ludowej. Obecnie moga być one wykorzystywane jako naturalne dodatki do kosmetyków, produktów spożywczych, leków. Należy więc dokładnie poznać tę grupę roślin, aby wykorzystać wszystkie jej wyjątkowe właściwości i zastosowania.

\section{Streszczenie}

Centaurea L. jest jednym z liczniejszych (czwartym, co do wielkości) rodzajów rodziny Asteraceae, należacym do grupy roślin okrytonasiennych (kwiatowych). Morfologia i chemizm tego rodzaju, wciąz jeszcze nie sa dobrze poznane. Obejmuje on najczęściej wieloletnie, ale również roczne i dwuletnie gatunki roślin trawiastych i krzewinek. Rośliny $z$ rodzaju Centaurea L. występuja głównie w obszarze Morza Śródziemnego i Zachodniej Azji. Rodzaj ten jest jednym $z$ najbogatszych pod względem występowania gatunków endemicznych. Szczególnie dużą liczbę gatunków Centaurea L. spotkać możemy w Turcji, głównie w południowo-zachodniej, centralnej i wschodniej części kraju. Badania etnofarmakologiczne tego rodzaju wykazały, że duża liczba tych roślin jest w wielu krajach używana w medycynie ludowej do leczenia różnych dolegliwości. W niniejszej pracy przedstawiono przegląd olejków eterycznych pozyskiwanych $z$ wybranych 50 gatunków roślin rodzaju Centaurea L., ze szczególnym uwzględnieniem ich składu i związków dominujących. Opisano właściwości olejków, na podstawie których wnioskować można potencjalne ich wykorzystanie w lecznictwie, przemyśle kosmetycznym czy spożywczym.

\section{LITERATURA}

Aktumsek A., Zengin G., Guler G. O., Cakmak Y. S., DURAN A., 2011. Screening for in vitro antioxidant properties and fatty acid profiles of five Centaurea L. species from Turkey flora. Food Chem. Toxic. 49, 2914-2920.

AktumseK A., Zengin G., Guler G. O., CAKMAK Y. S., DURAN A., 2013. Assessment of the antioxidant potential and fatty acid composition of four Centaurea L. taxa from Turkey. Food Chem. 141, 91-97.

Altintas A., Kose Y. B., Yucel E., Demirci B., BASER K. H. C., 2004. Composition of the es- 
sential oil of Centaurea dichroa. Chem. Nat. Compd. 40, 604-605.

Altintas A., Kose Y. B., KANDEMIR A., DEMIRCI B., BASER K. H. C., 2009. Composition of the essential oil of Centaurea saligna. Chem. Nat. Compd. 45, 267-277.

AsAdipour A., MeHrabani M., NAJAFi M. L., 2005. Volatile oil composition of Centaurea aucher (DC.) Wagenitz. DARU 13, 160-164.

Bagamboula C. F., UytTEndaele M., DebeVere J., 2004. Inhibitory effect of thyme and basil essential oils, Centaurea L., thymol, estragol, linalool and p-cymene towards Shigella sonne and S. flexneri. Food Microbiol. 21, 33-42.

BAHI A., AL MANSOURI S., AL MEMARI E., AL AMERI M., NURUlain S. M., OJHA S., 2014. $\beta$-Caryophyllene, a CB2 receptor agonist produces multiple behavioral changes relevant to anxiety and depression in mice. Physiol. Behav. 135, 119-124.

BASER K. H. C., 2008. Biological and pharmacological activities of carvacrol and carvacrol bearing essential oils. Curr. Pharm. Des.14, 3106-3119.

Baser K. H. C., OzeK G., OzeK T., Duran A., 2006. Composition of the essential oil of Centaurea huber-morathii Wagenitz isolated from seeds by microdistillation. Flav. Frag. J. 21, 568-570.

BŸlent Kose Y., Iscan G., Demirci B., Baser K. H. C., CELIK S., 2007. Antimicrobial activity of the essential oil of Centaurea aladagensis. Fitoterapia 78, 253-254.

Chavan M. J., WAKTE P. S., Shinde D. B., 2010. Analgesic and antiinflammatory activity of caryophyllene oxide from Annona squamosa $L$. bark. Phytomedicine 17, 149-151.

CHIOU L.-C., LING J.-Y., CHANG C.-C., 1997. Chinese herb constituent $\beta$-eudesmol alleviated the electroshock seizures in mice and electrographic seizures in rat hippocampal slices. Neurosci. Lett. 231, 171-174.

Ditomaso J. M., KYSER G. B., ONETO S. R., WiLSON R. G., ORLOFF S. B., ANDERSON L. W. Wright S. D., RONCORONI J. A., Miller T. L., Prather T. S., Ransom C., Beck K. G., DUNCAN C., WILSON K. A., MANN J. J., 2013. Weed control in natural areas in the Western United States. Weed Research and Information Center, University of California.

Dob T., Dahmane D., GaURIaT-Desrdy B., DaliGAULT V., 2009. Essential Oil Composition of Centaurea pullata L. J. Essent. Oil Res. 21, 417-422.

Dural H., Bagci Y., ERTugrul K., Demirelma H., Flamini G., Cioni P. L., MoRelli I., 2003. Essential oil composition of two endemic Centaurea species from Turkey, Centaurea muconifera and Centaurea chrysantha, collected in the same habitat. Biochem. Syst. Ecol. 31, 14171425.

Dydak M., Kolano B., NOWAK T., Siwińska D., MALUSZYŃSKA J., 2009. Cytogenetic studies of three European species of Centaurea L. (Asteraceae). Hereditas 146, 152-161.

EREL S. B., KARAALP C., BEDIR E., KAEHLiG H., Glasl S., KHAN S., KRENN L., 2011. Secondary metabolites of Centaurea calolepis and evaluation of cnicin for anti-inflammatory, antioxidant, and cytotoxic activities. Pharmaceut. Biol. 49, 840-849.

Ertas A., GÖREN S.C., Boga M., DemirCi S., KoLAK U., 2014. Chemical composition of the essential oils of three Centaurea species growing wild in Anatolia and their anticholinesterase activities. J. Essent. Oil-Bear. Pl. 17, 922926.

Ertugrul K., Dural H., Tugay O., Flamini G., CiONI P. L., MORELLI I., 2003. Essential oils from flowers of Centaurea kotschyi var. kotschyi and C. kotschyi var. decumbens from Turkey. Flavour Frag. J. 18, 95-97.

ESMAEILI A., RUSTAIYAN A., NADIMI M., 2005. Volatile constituents of Centaurea depressa M.B. and Carduus pycnocephalus L. two compositae herbs growing wild in Iran. J. Essent. Oil Res. 17, 539-541.

Flamini G., ERTugrul K., Cioni P. L., Morelli I., DURAL H., BAGCI Y., 2002. Volatile constituents of two endemic Centaurea species from Turkey: C. pseudoscabiosa subsp. pseudoscabiosa and C. hadimensis. Biochem. Syst. Ecol. 30, 953-959.

Flamini G., Tebano M., Cioni P. L., Bagci Y., DURAL H., ERTUGRUL K., UYSAL T., SAVRAN A., 2006. A multivariate statistical approach to Centaurea classification using essential oil composition data of some species from Turkey. Pl. Syst. Evol. 261, 217-228.

Formisano C., Rigano D., Senatore F., Celik S., BRUNO M., ROSSElli S., 2008. Volatile constituents of aerial parts of three endemic Centaurea species from Turkey: Centaurea amanicola Hub.-Mor., Centaurea consanguinea DC. and Centaurea ptosimopappa Hayek and their antibacterial activities. Nat. Prod. Res. 22, 833-839.

Ghelardini C., Galeotti N., Di Cesare MannelLI L., MAZZANTI G., BARTOLINI A., 2001. Local anaesthetic activity of $\beta$-caryophyllene. Il Farmaco 56, 387-389.

KAHRIMAN N., TOSUn G., YlmaZ ISKENDERA N., ALPAY KARAOGLU S., YAYLI N., 2012. Antimicrobial activity and a comparative essential oil analysis of Centaurea pulcherrima Willd. var. pulcherrima extracted by hydrodistillation and microwave distillation. Nat. Prod. Res. 26, 703-712.

Karamenderes C., Demirci B., Baser K. H. C., 2008. Composition of essential oils of ten Centaurea L. taxa from Turkey. J. Essent. Oil Res. 20, 342-349.

KIERZEK R., 2015. Strategia przeciwdziałania odporności chabra bławatka $i$ miotły zbożowej na herbicydy. Instytut Ochrony Roślin - Państwowy Instytut Badawczy, Poznań.

Koca U., Suntar I. P., Keles H., Yesilada E., AKKOL E. K., 2009. In vivo anti-inflammatory and wound healing activities of Centaurea iberica Trev. ex Spreng. J. Ethnopharmacol. 126, 551-556.

KoHLMÜnZER S., 1998. Farmakognozja. Podręcznik dla studentów farmacji. Wydawnictwo Lekarskie PZWL, Warszawa.

Kose Y. B., Altintas A., Demirci B., CeliK S., BASER K. H. C., 2009. Composition of the essential oil of endemic Centaurea paphlagonica (Bornm.) Wagenitz from Turkey. Asian J. Chem. 21, 1719-1724.

Lazari D. M., Skaltsa H. D., Constantinidis T., 2000. Volatile constituents of Centaurea pelia D.C., C. thesala Hausskn. subsp. drakiensis (Freyn \& Sint.) Georg. and C. zuccariniana DC. from Greece. Flavour Fragr. J. 15, 7-11.

Milosević T., Argyropoulou C., Solujić S., MuRAT-SPAHIC D., SKalTSA H., 2010. Chemical composition and antimicrobial activity of essential oils from Centaurea pannonica and $C$. jacea. Nat. Prod. Commun. 5, 1663-1668.

MOLSKI M., 2012. Chemia piękna. Wydawnictwo Naukowe PWN, Warszawa. 
MOZURAITIS R., STRANDEN M., RAMIREZ M. I., BORG-KARLSON A.-K., MUSTAPARTA H., 2002. (-)-Germacrene $D$ increases attraction and oviposition by the tobacco budworm moth Heliothis virescens. Chem. Sens. 6, 505-509.

NoGe K., BECERRA J. X., 2009. Germacrene D, A common sesquiterpene in the genus Bursera (Burseraceae). Molecules 14, 5289-5297.

PietrZAK B., DUNAJ A., PIĄTKOWSKA K., 2011. Rola układu kannabinoidowego $\mathrm{w}$ patogenezie oraz poszukiwaniu nowych możliwości farmakoterapii zespołu zależności alkoholowej. Post. Hig. Med. Dośw. 65, 606-615.

Politeo O., SKocibusic M., Carev I., Burcul F., Jerkovic I., SAROLIC M., Milos M., 2012. Phytochemical profiles of volatile constituents from Centaurea ragusina leaves and flowers and their antimicrobial effects. Nat. Prod. Comm. 7, 1087-1090.

Rosselli S., Btuno M., Maggio A., Raccuglia R. A., Bancheva S., Senatore F., Formisano C., 2009. Essential oils from aerial parts of Centaurea cuneifolia Sibth. \& Sm. and C. euxina Velen., two species growing wild in Bulgaria. Biochem. Syst. Ecol. 37, 426-431.

SCHMIDT C. O., BOUWMEESTER H. J., DE KRAKER J. W., KÖNIG W. A., 1998. Biosynthesis of (+)and (-)-germacrene $D$ in Solidago canadensis: isolation and characterization of two enantioselective germacrene $D$ synthases. Angew. Chem. Int. Ed. 37, 1400-1402.

Senatore F., Rigano D., De Fusco R., Bruno M., 2003. Volatile components of Centaurea cineraria L. subsp. umbrosa (Lacaita) Pign. and Centaurea napifolia L. (Asteraceae), two species growing wild in Sicily Flavour Fragr. J. $18,248-251$.

SenATORE F., APOSTOlides-ARnold N., BRUno M., 2005. Volatile components of Centaurea eryngioides Lam. and Centaurea iberica Trev. var. hermonis Boiss. Lam., two Asteraceae growing wild in Lebanon. Nat. Prod. Res.19,749-754.

SEnATORE F., LANDOlFi S., CELIK S., BRUNO M., 2006. Volatile components of Centaurea calcitrapa L. and Centaurea sphaerocephala $L$. ssp. sphaerocephala, two Asteraceae growing wild in Sicily. Flavour Fragr. J. 21, 282-285.

Senatore F., Formisano C., Raio A., Bellone G., BRUNO M., 2008. Volatile components from flower-heads of Centaurea nicaeensis All., C. parlatoris Helder and C. solstitialis L. Ssp. schouwii (DC.) Dosta'l growing wild in southern Italy and their biological activity. Nat. Prod. Res. 22, 825-832.

Vasudevan A., Dileep K. V., Mandal P. K., KaRTHE P., SADASIVAN C., HARIDAS M., 2012. Anti-Inflammatory property of n-hexadecanoic acid: structural evidence and kinetic assessment. Chem. Biol. Drug Des. 80, 434-439.

YANG D., Michel L., ChAUMONT J. P., Millet-CleRC J., 1999. Use of caryophyllene oxide as an antifungal agent in an in vitro experimental model of onychomycosis. Mycopathologia $148,79-82$.

YANishlieVA N. V., MARINOVAa E. M., GoRDONB M. H., RanevaA V. G., 1999. Antioxidant activity and mechanism of action of thymol and carvacrol in two lipid systems. Food Chem. 64, 5966.

Yayli N., Yasar A., GŸlec C., Usta A., Kolayli S., Coskuncelebi K., KaraOglu S., 2005. Composition and antimicrobial activity of essential oils from Centaurea sessilis and Centaurea armena. Phytochemistry 66, 1741-1745.

YAYLI N., YAŞAR A., YAYLI N., Albay C., AŞAMAZ Y., COSKKUNÇELEBI K., KARAOĞLU S.,, 2009. Chemical composition and antimicrobial activity of essential oils from Centaurea appendicigera and Centaurea helenioides. Pharmaceut. Biol. 47, 7-12.

Yu F., HaRAda H., Yamasaki K., OKamoto S., HiRASE S., TANAKA Y., MISAWA N., UTSUMI R., 2008. Isolation and functional characterization of a b-eudesmol synthase, a new sesquiterpene synthase from Zingiber zerumbet Smith. FEBS Lett. 582, 565-572.

ZENGin G., AKTUMSEK A., GUler G. O., CAKMAK Y. S., KAN Y., 2012. Composition of essential oil and antioxidant capacity of Centaurea drabifolia Sm. subsp. detonsa (Bornm.) Wagenitz, endemic to Turkey. Nat. Prod. Res. 26, 1-10. 
KOSMOS Vol. 67, 2, 319-334, 2018

ALEKSANDRA JÓZEFCZYK, JOANNA KOWALSKA

Chair and Department of Pharmacognosy with Medicinal Plant Unit, Medical University of Lublin, Chodźki 1, 20-093 Lublin, E-mail: ajozefczyk@pharmacognosy.org

\section{COMPOSITION AND APPLICATION OF ESSENTIAL OILS FROM THE CENTAUREA L. PLANT GENUS}

\section{Summary}

Centaurea L. is one of a more numerous genus of the Asteraceae family, ranked among the group of Angiosperm plants (flowering plants), morphology and chemical composition of which are still not well known. Most often it includes long-term plant species, but also annual and two-year species of Graminaceous plants and shrubs. Plants from the Centaurea L. genus are found mainly in an area of the Mediterranean Sea and Western Asia. This genus is one of the richest in terms of occurrence of endemic species. Particularly large amounts of Centaurea L. species live in Turkey, mainly in south-west, central and of eastern part of the country. Ethnopharmacological examinations of the genus showed that a substantial amount of these plants in many countries is being used in the folk medicine for curing various ailments. In this paper essential oils acquired from 50 chosen species of the Centaurea L. plants are described, with particular reference to their chemical composition and properties important from the point of view of their possible application in health care, cosmetics and food industries.

Key words: Centaurea L. genus, chemical composition, essential oils, pharmacological properties 